\title{
Evaluation of Financial Viability of Woodlots and Crops in Coast Region of Kenya
}

\author{
Wekesa L. , Muema K., Muthini J. \\ Coast Eco-Region Research Programme, Kenya Forestry Research Institute, Kenya
}

Received October 5, 2021; Revised December 24, 2021; Accepted January 16, 2022

\begin{abstract}
Cite This Paper in the following Citation Styles
(a): [1] Wekesa L., Muema K., Muthini J. , "Evaluation of Financial Viability of Woodlots and Crops in Coast Region of Kenya," Universal Journal of Agricultural Research, Vol. 10, No. 1, pp. 27 - 37, 2022. DOI: 10.13189/ujar.2022.100103.
\end{abstract}

(b): Wekesa L., Muema K., Muthini J. (2022). Evaluation of Financial Viability of Woodlots and Crops in Coast Region of Kenya. Universal Journal of Agricultural Research, 10(1), 27 - 37. DOI: 10.13189/ujar.2022.100103.

Copyright $\bigcirc 2022$ by authors, all rights reserved. Authors agree that this article remains permanently open access under the terms of the Creative Commons Attribution License 4.0 International License

\begin{abstract}
Majority of farmers in the Coast Region of Kenya practice the agri-silviculture farming system as a source of their livelihood and well-being. However, most of them grow trees and agriculture crops on smallholdings that are characterized by a limited resource base calling for the adoption of enterprises with the potential of optimizing production and economic returns. Thus, financial assessments were carried out for both the trees and agriculture crops to establish profitable ones. The study was carried out as a cross-sectional survey using a questionnaire to collect data from smallholder farmers with woodlots and field crops selected using stratified random sampling procedures. The results reveal that woodlots were more profitable at their biological rotation than commonly grown field crops. Woodlots had average annual net earnings of US\$364.46 per acre spread uniformly over their biological rotation. On the other hand, annual earnings from highly ranked field crops averaged US\$177.39 per acre. It was, therefore recommended that farmers be encouraged to engage in woodlots but inter-crop them with field crops at the initial stages of establishment to help diversify, and optimize their incomes and food self-sufficiency at the farm level. Farmers are also advised to mechanize and use other technologies that minimize labour usage that was observed to be the highest cost component in woodlot establishment.
\end{abstract}

Keywords Benefits, Costs, Optimize, Profitability

\section{Introduction}

The establishment of woodlots on smallholdings in the Coast Region of Kenya is on an upward trend as farmers explore ways of optimizing and diversifying their livelihoods and well-being. Apart from woodlots, smallholder farmers are also engaged in crop farming and other farm activities resulting in farming systems that are categorized as: agri-silvi-pastoral (combination of forest tree crop, agriculture crop, and pasture and/or animal); agri-silvicultural (combination of the forest tree crop and agriculture crop) and/or silvi-pastoral (combination of forest tree and pasture and/or animal) systems. The agri-silvicultural system which is common in the region offers a complex farming system that presents an intermix of field crops and woodlots. The field crops grown are wide and varied depending on the need and preferences of the farmer. Equally, the woodlots are wide ranging including exotic and indigenous timber and round wood species like Casuarina equisetifolia (Whistling pine), Melia volkensii (Melia), Tectona grandis (Teak), Eucalyptus camaldulensis (River red gum), Gmelina arborea (Gmelina), and Milicia excelsa (African teak). However, as farms become increasingly smaller through subdivisions as evident in the region, the need to concentrate on activities that optimize productivity and incomes becomes critical. Profitability assessment is important to establish the gains and losses [1]. Thus, farmers require information on the profitability of farm enterprises to enable them make appropriate choices on which ones to adopt. 
Various studies have been undertaken to help create an understanding of the resource allocation and profitability of various farm enterprises undertaken on smallholdings. In a study of on-farm activities that would optimize incomes in addition to the main activity of livestock rearing in the Southern Rangelands of Kenya, [2] found fruit production as the most profitable enterprise among trees and field crops on smallholder farms. Senelwa [3] in a study on farmer perceptions towards tree growing and profitability in the Western region of Kenya observed that more farmers were slowly shifting from wheat and maize growing in favour of tree growing that provided more money and was less demanding in resource requirements. Although the studies demonstrate the profitability of trees and their choice over field crops, they focused on a limited number of woodlots and crops. In addition, the biological rotation of the woodlots and comparative analysis of their costs and benefits with competing crops were not adequately accounted for by the analyses. The ecological set-ups and socio-economic perspectives of sites covered by the studies were dissimilar from those of the coast. Based on the site differences and unresolved issues in the past studies, this study provides an empirical analysis of data collected to better understand the profitability of woodlots and field crops by addressing the main question: what are the most profitable farm enterprises on smallholder farms in the coast?

The evaluation of the financial viability of woodlots and competing field crops in the coast is novel and makes contributions relative to the existing literature on smallholder farm enterprises. Previous studies within the Kenyan context [2], [3], [4], [5], [6], [7] have examined the profitability of farm enterprises but in different eco-systems and under different socio-economic set-ups. The study by Wekesa et al. [8] that looks at the economics of woodlots on smallholder farms in the region does not make a comparative profitability analysis of existing farm enterprises. There is inadequate empirical evidence that informs on the comparative profitability of woodlots and field crops as commonly practiced enterprises on smallholdings in the coast. We, therefore add value by examining the profitability of woodlots and field crops in the coast which is a unique ecological set-up with unparalleled socio-economic conditions. Lastly, we make a comparative financial analysis of woodlots with competing field crops that had not been captured in economic assessment by previous studies in the region.

The study is anchored on the neo-classical theory of the firm which like the traditional theory assumes that the entrepreneur is also the owner of the firm and that the firm has a single goal of profit maximization, that is to create as much of a gap between revenue and costs [9]. However, the neoclassical theory deals with the determination of the time-horizon, the long-run period in woodlot investment. The woodlots take years before returns are realized; the length of time taken has implications on the costs of production and benefits realized [8]. The cost/benefit approach of Annual Equivalent Value (AEV) was applied to compute the profitability of the woodlots and field crops. The AEV is the annual net earnings spread uniformly over the biological rotation of a farm enterprise.

The study establishes the most profitable enterprises with the potential of helping farmers to optimize returns from their holdings. Costs and benefits were computed resulting in profitability levels of the enterprises. The commonly grown forest trees or woodlots included $M$. volkensii, C. equisetifolia, E. camaldulensis, G. arborea and $M$. excelsa. The field crops grown on the farms included maize, beans, cowpeas, cassava, and green grams. Thus, an analysis was done using descriptive statistics to establish their ranking by the farmers/investors. Costs and benefits of the highly ranked woodlots and field crops were established and a comparative analysis was done to establish the most profitable enterprises on smallholdings.

The paper is presented as follows: introduction; methods; results; discussion; and conclusion and recommendation. An elucidation of existing farming systems on the smallholdings is offered. In particular, the focus is on the agri-silvicultural system which is the common farming system in the region. Resource allocation and profitability of farm enterprises undertaken on smallholdings are then reviewed and focus placed on the woodlots and field crops. Conceptual arguments and contextual issues are presented, and the knowledge gap and strategies for bridging it indicated. The study results are presented, and the paper winds up with the discussion, and conclusion and recommendation of the study.

\section{Methods}

\subsection{Study Area}

The study was conducted in the Coast Region (former Coast Province of Kenya) composed of six counties, namely; Kilifi, Kwale, Mombasa, Lamu, Tana River and Taita Taveta (See Figure 1). The region covers an area of $79,686.1 \mathrm{~km}^{2}$ and with a population of 4,329,474 as per the national population census of 2019 [10]. It has high poverty levels estimated at $69.7 \%$ which is far above the Kenyan average of $45.2 \%$. The larger part of the region is relatively dry, with a high variation in the amount of rainfall that is bimodal with long rains (March-July) and short rains (October-December) ranging from $508 \mathrm{~mm}$ in the drier northern hinterland to over $1,016 \mathrm{~mm}$ in the wetter areas along the coastline [11]. 


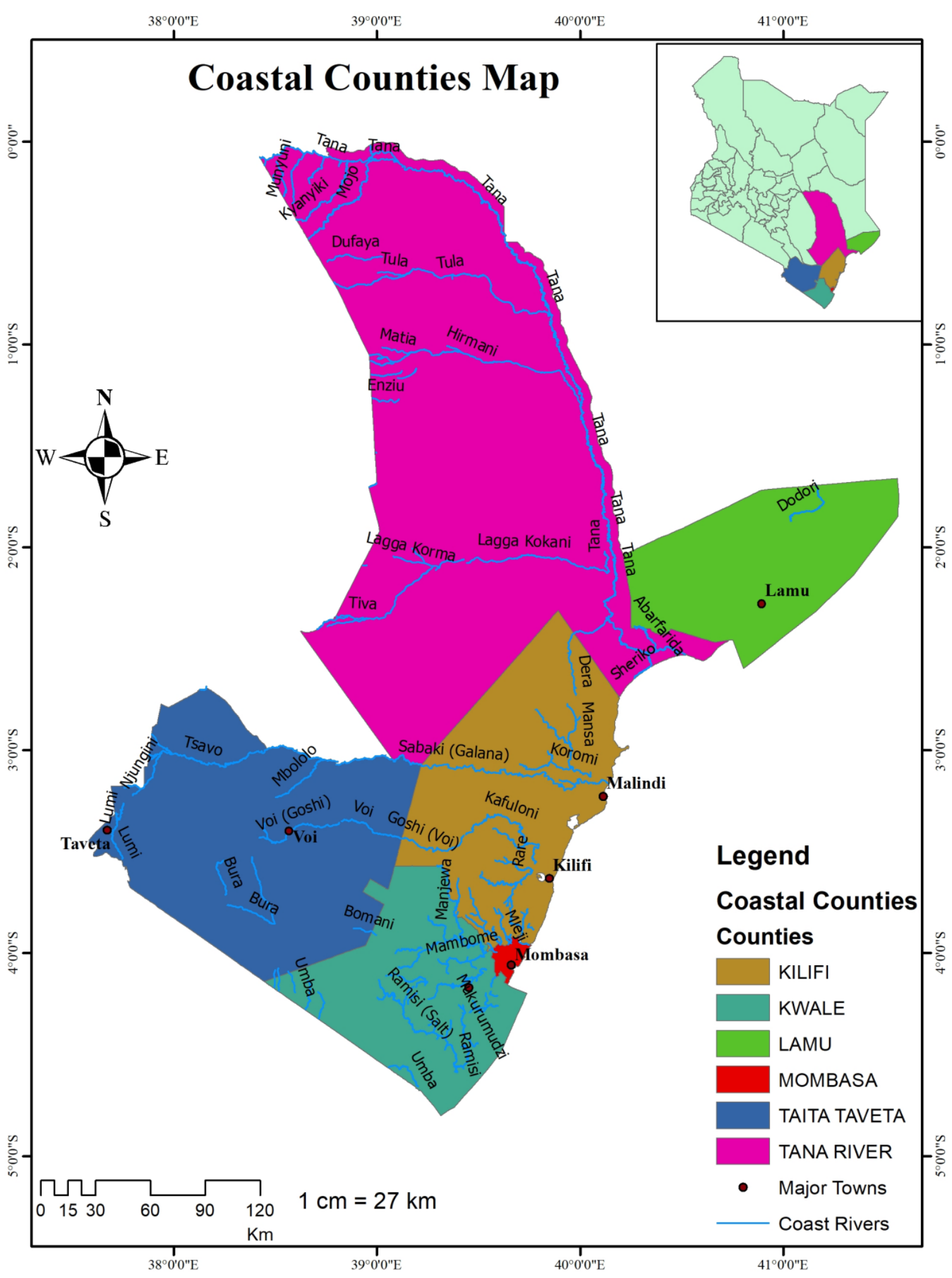

Figure 1. Map showing Coastal Counties

The key economic activities include agriculture, tourism, fisheries, shipping, mining, and manufacturing. Agricultural activities include agricultural crops, livestock rearing, and forest tree farming forming three farming systems: agri-silvi-pastoral; agri-silvicultural; and silvi-pastoral systems. Agriculture crop farming together with trees is common in more humid parts of the region found along the coastal strip in the counties of Kilifi, Kwale and Lamu. About $21.3 \%(1,707,625$ ha and mainly along the coastal strip) is classified as a high crop capability zone, $0.27 \%(21,871 \mathrm{ha})$ as a medium crop capability zone, and $78 \%$ as low crop capability zone [12]. 


\subsection{Sampling Design}

The study was carried out as a cross-sectional survey of smallholder farms undertaking agriculture crops and forest trees/woodlots production. The survey also covered model farms run by companies like Komaza and Bamburi Lafarge. The Bamburi Cement Ltd of Lafarge Holcim through its subsidiary company of Lafarge Eco Systems Limited (LES) uses a rehabilitation and restoration approach to sustainably utilize its lands and quarries by involving local communities and other stakeholders. The study used the database maintained by Kenya Forestry Research Institute (KEFRI) on smallholder farms engaged in both agriculture crops and woodlots production. The database had 1, 375 smallholder farmers engaged in both crop and tree farming that formed the population with the highest in Kilifi (41\%), Kwale (24\%) and Lamu (18\%). A representative sample for the study was selected from this finite population of smallholders. The sample size was computed in two stages using equations 1 and 2 . The first stage involved computing sample size without considering the finite population correction factor using equation 1 .

$$
n_{0}=\frac{Z^{2} \mathrm{p}(1-\mathrm{p})}{d^{2}}
$$

where: $\mathrm{Z}$ was 1.96 as the degree of confidence at $95 \%$ confidence level; $\mathrm{p}$ was 0.5 as the proportion in the population having measured characteristics chosen at $50 \%$ [13]; d was 0.05 as the level of statistical significance at $5 \%$; and $n_{0}$ equaled 384 as the sample size without considering finite population correction factor. The second stage involved computation of the desired sample size (n) considering the correction factor for finite population $(\mathrm{N})$ by using equation 2 ; this resulted to a study sample size of 282 , which was $20.5 \%$ of the target population of the smallholders. This sample size was closer to 300 which is demonstrated by studies as good size [14].

$$
n=\frac{n_{0} \mathrm{~N}}{n_{0}+(\mathrm{N}-1)}
$$

Multi-stage stratified random sampling was applied to establish sampling units for the study. At stage I, the region was classified into administrative counties and Kilifi, Kwale and Lamu Counties that had the highest concentration of smallholders (83\%) engaged in growing both the trees and agriculture crops selected (Table 1). The three counties formed about $34 \%$ of the total area and $57 \%$ of the total human population of the region. At stages II and III, sub-counties and villages, respectively in the selected counties were listed and those with the highest number of smallholders practicing both agriculture crop farming and tree woodlots selected. The sample units were established proportionately by multiplying the sample size with a fraction of smallholders in each sampled county to the total population. All the smallholders in each sampled county were then numbered sequentially and random numbers used to select the ones for interviews in Kilifi (140), Kwale (81) and Lamu (61).

\begin{tabular}{|c|c|c|c|c|c|}
\hline $\begin{array}{c}\text { Sampling } \\
\text { stage }\end{array}$ & Sampling frame & Description & & Select & units \\
\hline Stage I & List of all coastal counties & $\begin{array}{l}\text { Counties with highest concentration of } \\
\text { smallholders engaged in crop and tree } \\
\text { farming }\end{array}$ & Kilifi & Kwale & Lamu \\
\hline Stage II & $\begin{array}{l}\text { List of all sub-counties in } \\
\text { selected counties }\end{array}$ & $\begin{array}{l}\text { Sub-counties with highest concentration of } \\
\text { smallholders engaged in crop and tree } \\
\text { farming }\end{array}$ & $\begin{array}{c}\text { Gaze } \\
\text { Malindi Magarini }\end{array}$ & $\begin{array}{l}\text { Msambweni } \\
\text { Matuga } \\
\text { Kinango } \\
\end{array}$ & $\begin{array}{c}\text { Mpeketoni } \\
\text { Witu } \\
\text { Hindi } \\
\end{array}$ \\
\hline \multirow{5}{*}{ Stage III } & \multirow{5}{*}{$\begin{array}{l}\text { List of all villages in } \\
\text { selected sub-counties }\end{array}$} & \multirow{5}{*}{$\begin{array}{l}\text { Villages with highest concentration of } \\
\text { smallholders engaged in crop and tree } \\
\text { farming }\end{array}$} & Ganze & Msambweni & Mpeketoni \\
\hline & & & Matano mane & Maphombe & Bomani \\
\hline & & & Mijomboni & Shimbahills & Witu \\
\hline & & & Gede & Taru & Soroko \\
\hline & & & Magarini & Samburu & Hindi \\
\hline Stage IV & $\begin{array}{l}\text { List of smallholders in } \\
\text { selected villages }\end{array}$ & $\begin{array}{l}\text { Random selection of smallholders involved } \\
\text { in crop and tree farming }\end{array}$ & 140 & 81 & 61 \\
\hline
\end{tabular}

Table 1. Multi-stage Stratified Random Sampling for Smallholders Engaged in Crop and Tree Farming in Coast 


\subsection{Data Collection and Data Analysis}

A questionnaire with open and closed format questions was used in data collection. The questionnaire as a tool offers opportunities for vast coverage, speed, cost-effectiveness and versatility [15]. Target respondents were owners of the smallholder farms, however, in cases where it was not possible to interview them either due to unavailability or literacy concerns, their spouses or farm managers were interviewed. The data collected was on types of farm enterprises, and their acreage, inputs and outputs from Kilifi, Kwale and Lamu Counties.

Questionnaires from 102 smallholder farms had satisfactory answers indicating $36 \%$ response rate. Following data cleaning process, 80 questionnaires (Kilifi 41, Kwale 27 and Lamu 22) were found usable and adopted in this study for financial evaluation of farm enterprises. The production and transaction costs and benefits from data collected were applied in computing the Annual Equivalent Value (AEV) to assess profitability of highly ranked farm enterprises. The interest rate on capital of $10 \%$ and annual inflation rate of $7.60 \%$ computed as average from 2010 to 2017 were used in the analysis. The data on costs and benefits was in Kenya Shillings (KES) and converted to US dollars (US\$) using currency conversion of 100 KES: 1 US\$. The benefits were collected as the revenues realized from sales of field crops produce and woodlot trees at stumpage. Stumpage is the market value of standing trees that must be paid for the right to harvest [16]. Descriptive statistics including means were applied to establish three highly ranked farm enterprises each from the crops and woodlots for computing the AEVs.

The AEV combines all costs and benefits (revenues) into a single sum that is equivalent to all cash flows during an analysis period spread uniformly over the production period or biological rotation of trees; rotation for C. equisetifolia at 4 years for poles, and G. arborea and $M$. volkensii for timber at 15 years [8]. It is an annual payment that would pay off the Net Present Value (NPV) of a farm enterprise over its production period [17], that is:

$$
A E V=\left(\sum_{t-1}^{n} \frac{B_{t}-C_{t}}{(1+r)^{t}}\right) * \frac{r(1+r)^{t}}{(1+r)^{t}-1}=N P V * \frac{r(1+r)^{t}}{(1+r)^{t}-1}
$$

where $\mathrm{AEV}$ is annual equivalent value, $\mathrm{Bt}$ is benefit (revenue) in each year, $\mathrm{Ct}$ is cost in each year, $\mathrm{t}$ is time period, $\mathrm{n}$ is the production period/biological rotation (time period for a woodlot to be ready for harvesting) in years and $r$ is the discount rate. NPV is the present value of all benefits $(\Sigma \mathrm{Bt})$ less the present value of all costs $(\Sigma \mathrm{Ct})$.

The study used cross-sectional data which does not allow for an understanding of causal effect of farm enterprises on welfare of owners/entrepreneurs. Determination of causal effects was beyond scope of the study and thus had no impact on the outcome of the analysis. However, the study faced limitation of external validity of the findings from cost/benefit approaches; replicability of findings from AEV calculations could not be guaranteed because of high variability in costs and yields between farms and sites. However, we enhanced validity of our findings through use of highly skilled and experienced enumerators. Experienced team composed of foresters from KEFRI administered the questionnaires and ensured that data on costs of production and derived revenue was recorded accurately. The standard errors (SE) of mean were computed as an indication of reliability of mean. A small SE indicates that sample mean is more of an accurate reflection of actual population mean.

\section{Results}

Decision making process on smallholder farms involves making choices on the enterprises that would optimize incomes. Therefore, an analysis was conducted to establish the ranking of woodlots and field crops and their profitability. The descriptive statistics were used to establish the ranking scores of the farm enterprises while NPV and AEV were computed to establish their profitability. A summary of the statistics of the respondents' demographic/farm background including acreage, and other informative background is summarized in Table 2.

From Table 2, the majority surveyed were male (70\%) with average age of 57 years and household size of 6 family members. Equally, the majority were lower income earners $(70 \%)$ and operated farms averaging 9 acres. Across the counties, Kwale County had the highest percentage of female farmers $(42 \%)$ and those with tertiary levels of education (13\%) surveyed. The majority (90\%) covered in Lamu County were lower income earners. The average household and land sizes in the three counties covered were similar, averaging 6 members and 9 acres, respectively. 
Table 2. Respondents' Demographic/Farm Background

\begin{tabular}{|c|c|c|c|c|c|c|c|c|}
\hline \multirow{2}{*}{ Item } & \multicolumn{2}{|c|}{ Kilifi } & \multicolumn{2}{|c|}{ Kwale } & \multicolumn{2}{|c|}{ Lamu } & \multicolumn{2}{|c|}{ Total } \\
\hline & Counts & $\%$ & Counts & $\%$ & Counts & $\%$ & Counts & $\%$ \\
\hline $\mathrm{N}$ & & & & & & & 80 & \\
\hline Male & 32 & 70 & 7 & 58 & 17 & 77 & 56 & 70 \\
\hline Female & 14 & 30 & 5 & 42 & 5 & 23 & 24 & 30 \\
\hline Household size & 6 & & 6 & & 6 & & 6 & \\
\hline Lower income (US\$ 236.70 and below) & 27 & 64 & 10 & 59 & 19 & 90 & 56 & 70 \\
\hline Middle income (US\$ $236.71-1,199.00$ ) & 15 & 36 & 5 & 29 & 2 & 10 & 22 & 27.5 \\
\hline High income (above US\$ $1,199.00$ ) & 0 & 0 & 2 & 12 & 0 & 0 & 2 & 2.5 \\
\hline Primary level of education & 15 & 38 & 10 & 63 & 7 & 29 & 32 & 40 \\
\hline Secondary level of education & 17 & 43 & 2 & 13 & 15 & 63 & 34 & 43 \\
\hline Tertiary level of education & 3 & 8 & 2 & 13 & 2 & 8 & 7 & 9 \\
\hline Illiterate & 5 & 13 & 2 & 13 & 0 & 0 & 7 & 9 \\
\hline Mean land size in acres & 9 & & 10 & & 9 & & 9 & \\
\hline Mean age in years & 59 & & 61 & & 52 & & 57 & \\
\hline
\end{tabular}

Table 3. Ranking of Trees in Coast Counties

\begin{tabular}{|c|c|c|c|c|c|c|c|c|c|c|c|c|c|c|c|c|c|}
\hline \multirow{2}{*}{$\begin{array}{c}\text { County } \\
\text { Trees }\end{array}$} & & \multicolumn{4}{|c|}{ Kilifi } & \multicolumn{4}{|c|}{ Kwale } & \multicolumn{4}{|c|}{ Lamu } & \multicolumn{4}{|c|}{ Total } \\
\hline & & R1 & $\mathbf{R 2}$ & $\mathbf{R 3}$ & R4 & R1 & $\mathbf{R 2}$ & $\mathbf{R 3}$ & R4 & R1 & $\mathbf{R 2}$ & $\mathbf{R 3}$ & R4 & R1 & $\mathbf{R 2}$ & $\mathbf{R 3}$ & R4 \\
\hline \multirow{2}{*}{ A. occidentale } & $\mathrm{n}$ & 2 & 6 & 3 & 0 & 0 & 0 & 0 & 1 & 2 & 1 & 1 & 0 & 4 & 7 & 4 & 1 \\
\hline & $\%$ & 11.8 & 46.2 & 37.5 & 0 & 0 & 0 & 0 & 33.3 & 25.0 & 11.1 & 16.7 & 0 & 12.5 & 26.9 & 19.0 & 9.1 \\
\hline \multirow{2}{*}{ C. equestifolia } & $\mathrm{n}$ & 9 & 0 & 0 & 2 & 2 & 2 & 0 & 1 & 5 & 1 & 0 & 1 & 16 & 3 & 0 & 4 \\
\hline & $\%$ & 52.9 & 0 & 0 & 50.0 & 33.3 & 28.6 & 0 & 33.3 & 62.5 & 11.1 & 0 & 33.3 & 50 & 11.5 & 0 & 36.4 \\
\hline \multirow{2}{*}{ Citrus spp } & $\mathrm{n}$ & 1 & 0 & 0 & 0 & 0 & 3 & 1 & 0 & 1 & 3 & 0 & 1 & 2 & 5 & 1 & 1 \\
\hline & $\%$ & 5.9 & 0 & 0 & 0 & 0 & 43.9 & 16.7 & 0 & 12.5 & 33.3 & 0 & 33.3 & 6.3 & 19.2 & 4.8 & 9.1 \\
\hline \multirow{2}{*}{$\begin{array}{l}\text { Cocos nucifera } \\
\quad \text { (Coconut) }\end{array}$} & $\mathrm{n}$ & 2 & 1 & 0 & 0 & 1 & 1 & 1 & 0 & 0 & 2 & 1 & 0 & 5 & 4 & 2 & 0 \\
\hline & $\%$ & 11.8 & 7.7 & 0 & 0 & 50 & 14.3 & 16.7 & 0 & 0 & 22.2 & 16.7 & 0 & 15.6 & 15.4 & 9.5 & 0 \\
\hline \multirow{2}{*}{ E. camaldulensis } & $\mathrm{n}$ & 0 & 1 & 0 & 0 & 0 & 1 & 0 & 0 & 0 & 0 & 0 & 0 & 0 & 2 & 0 & 0 \\
\hline & $\%$ & 0 & 7.7 & 0 & 0 & 0 & 14.3 & 0 & 0 & 0 & 0 & 0 & 0 & 0 & 7.7 & 0 & 0 \\
\hline \multirow{2}{*}{ G. arborea } & $\mathrm{n}$ & 1 & 0 & 0 & 0 & 0 & 0 & 0 & 0 & 0 & 1 & 1 & 1 & 1 & 1 & 1 & 1 \\
\hline & $\%$ & 5.9 & 0 & 0 & 0 & 0 & 0 & 0 & 0 & 0 & 11.1 & 16.7 & 33.3 & 3.1 & 3.8 & 4.8 & 9.1 \\
\hline \multirow{2}{*}{ M. indica } & $n$ & 2 & 3 & 2 & 0 & 0 & 0 & 3 & 0 & 0 & 0 & 1 & 0 & 2 & 3 & 6 & 0 \\
\hline & $\%$ & 11.8 & 23.1 & 25.0 & 0 & 0 & 0 & 50 & 0 & 0 & 0 & 6.7 & 0 & 6.3 & 11.5 & 28.6 & 0 \\
\hline \multirow{2}{*}{ M. volkensii } & $\mathrm{n}$ & 0 & 0 & 0 & 1 & 0 & 0 & 0 & 0 & 0 & 0 & 1 & 0 & 0 & 0 & 1 & 1 \\
\hline & $\%$ & 0 & 0 & 0 & 25 & 0 & 0 & 0 & 0 & 0 & 0 & 16.7 & 0 & 0 & 0 & 4.8 & 9.1 \\
\hline \multirow{2}{*}{ Total } & $\mathrm{n}$ & 17 & 13 & 8 & 5 & 6 & 7 & 6 & 3 & 8 & 9 & 6 & 3 & 32 & 26 & 21 & 11 \\
\hline & $\%$ & 100 & 100 & 100 & 100 & 100 & 100 & 100 & 100 & 100 & 100 & 100 & 100 & 100 & 100 & 100 & 100 \\
\hline
\end{tabular}

Key: $\mathrm{R}=$ rank; $\mathrm{n}=$ sum of respondents; $\%=$ percent of total sum of respodents

\section{Ranking of Farm Forestry Enterprises}

Ranking of the various tree species used for establishing woodlots on the smallholder farms was performed using frequency tables and the results are presented in Table 3. From Table 3, C. equisetifolia (50\%) was ranked top among the trees on smallholdings in the coast. On the other hand, E. camaldulensis ranked least among the indicated trees on the farms. The second and third ranked trees on the farms were Anacardium occidentale [Cashewnuts (26.9\%)] and Mangifera indica [Mango (28.6\%)], respectively. The Citrus spp (Citrus), G. arborea and $M$. volkensii tied as the fourth ranked trees at $9.1 \%$. 
The $C$. equisetifolia was top ranked species in Kilifi (52.9\%), Kwale (33.3\%) and Lamu (62.5\%) Counties. The second ranked species were $A$. occidentale in Kilifi (46.2\%), and citrus in Kwale (43.9\%) and Lamu (33.3\%). In these rankings, $C$. equisetifolia, G. arborea and $M$. volkensii emerged as the top three woodlots as the rest formed commodity tree crops as per the definition by [18] that woodlots are clusters of trees usually growing outside of forests on cropland and in human settlements.

Equally, ranking of the field crops commonly planted on the smallholder farms was conducted and the results are presented in Table 4. From Table 4, the top ranked field crop planted on the farms was maize $(80 \%)$. The second, third and fourth highly ranked field crops were cowpeas $(42 \%)$, green grams $(27 \%)$ and cassava $(18 \%)$, respectively. The least ranked field crops were beans and sorghum.

In the counties, maize ranked the highest in the three counties of Kilifi (94\%), Kwale (67\%) and Lamu (78\%). Equally, cowpeas ranked second in Kilifi (44\%), Kwale $(50 \%)$ and Lamu (33\%) while green grams ranked third in Kilifi (22\%), Kwale (33\%) and Lamu (22\%). The field crops with zero ranking scores in the counties included bixa (Kilifi), cotton, watermelon, simsim and sorghum (Kwale), and cassava, sorghum and beans (Lamu).

Table 4. Ranking of Field Crops in Coast

\begin{tabular}{|c|c|c|c|c|c|c|c|c|c|c|c|c|c|c|c|c|c|}
\hline \multirow{2}{*}{$\begin{array}{l}\text { County } \\
\text { Crop }\end{array}$} & & \multicolumn{4}{|c|}{ Kilifi } & \multicolumn{4}{|c|}{ Kwale } & \multicolumn{4}{|c|}{ Lamu } & \multicolumn{4}{|c|}{ Total } \\
\hline & & R1 & $\mathbf{R 2}$ & $\mathbf{R 3}$ & R4 & R1 & $\mathbf{R 2}$ & $\mathbf{R 3}$ & R4 & R1 & $\mathbf{R 2}$ & $\mathbf{R 3}$ & R4 & R1 & $\mathbf{R 2}$ & $\mathbf{R 3}$ & R4 \\
\hline \multirow{2}{*}{ Maize } & $\mathrm{n}$ & 17 & 0 & 0 & 0 & 4 & 0 & 0 & 0 & 7 & 2 & 0 & 0 & 28 & 2 & 0 & 0 \\
\hline & $\%$ & 94 & 0 & 0 & 0 & 67 & 0 & 0 & 0 & 78 & 22 & 0 & 0 & 80 & 6 & 0 & 0 \\
\hline \multirow{2}{*}{ Cowpeas } & $\mathrm{n}$ & 1 & 8 & 4 & 0 & 2 & 3 & 0 & 0 & 0 & 3 & 3 & 0 & 3 & 14 & 7 & 0 \\
\hline & $\%$ & 6 & 44 & 22 & 0 & 33 & 50 & 0 & 0 & 0 & 33 & 33 & 0 & 9 & 42 & 21 & 0 \\
\hline \multirow{2}{*}{ Cotton } & $\mathrm{n}$ & 0 & 0 & 1 & 0 & 0 & 0 & 0 & 0 & 2 & 1 & 0 & 0 & 2 & 1 & 1 & 0 \\
\hline & $\%$ & 0 & 0 & 6 & 0 & 0 & 0 & 0 & 0 & 22 & 11 & 0 & 0 & 6 & 3 & 3 & 0 \\
\hline \multirow{2}{*}{ Green peas } & $\mathrm{n}$ & 0 & 5 & 4 & 2 & 0 & 1 & 2 & 1 & 0 & 0 & 2 & 3 & 0 & 6 & 8 & 6 \\
\hline & $\%$ & 0 & 28 & 22 & 11 & 0 & 17 & 33 & 17 & 0 & 0 & 22 & 33 & 0 & 18 & 27 & 18 \\
\hline \multirow{2}{*}{ Watermelon } & $\mathrm{n}$ & 0 & 1 & 0 & 1 & 0 & 0 & 0 & 0 & 0 & 0 & 0 & 1 & 0 & 1 & 0 & 2 \\
\hline & $\%$ & 0 & 6 & 0 & 6 & 0 & 0 & 0 & 0 & 0 & 0 & 0 & 11 & 0 & 3 & 0 & 6 \\
\hline \multirow{2}{*}{ Simsim } & $\mathrm{n}$ & 0 & 0 & 1 & 1 & 0 & 0 & 0 & 0 & 0 & 4 & 1 & 1 & 0 & 4 & 2 & 2 \\
\hline & $\%$ & 0 & 0 & 6 & 6 & 0 & 0 & 0 & 0 & 0 & 44 & 11 & 11 & 0 & 12 & 6 & 6 \\
\hline \multirow{2}{*}{ Cassava } & $\mathrm{n}$ & 0 & 1 & 2 & 5 & 0 & 0 & 3 & 1 & 0 & 0 & 0 & 0 & 0 & 1 & 5 & 6 \\
\hline & $\%$ & 0 & 6 & 11 & 28 & 0 & 0 & 50 & 17 & 0 & 0 & 0 & 0 & 0 & 3 & 15 & 15 \\
\hline \multirow{2}{*}{ Sorghum } & $\mathrm{n}$ & 0 & 1 & 1 & 0 & 0 & 0 & 0 & 0 & 0 & 0 & 0 & 0 & 0 & 1 & 1 & 0 \\
\hline & $\%$ & 0 & 6 & 6 & 0 & 0 & 0 & 0 & 0 & 0 & 0 & 0 & 0 & 0 & 3 & 3 & 0 \\
\hline \multirow{2}{*}{ Beans } & $\mathrm{n}$ & 0 & 0 & 1 & 0 & 0 & 1 & 1 & 0 & 0 & 0 & 0 & 0 & 0 & 1 & 2 & 0 \\
\hline & $\%$ & 0 & 0 & 6 & 0 & 0 & 17 & 17 & 0 & 0 & 0 & 0 & 0 & 0 & 3 & 6 & 0 \\
\hline \multirow[t]{2}{*}{ Bixa } & $\mathrm{n}$ & 0 & 0 & 0 & 0 & 0 & 0 & 0 & 1 & 0 & 0 & 0 & 1 & 0 & 0 & 0 & 2 \\
\hline & $\%$ & 0 & 0 & 0 & 0 & 0 & 0 & 0 & 17 & 0 & 0 & 0 & 11 & 0 & 0 & 0 & 6 \\
\hline
\end{tabular}

Key: $\mathrm{R}=$ rank; $\mathrm{n}=$ sum of respondents; $\%=$ percent of total sum of respodents 


\section{Costs and Benefits of Highly Ranked Farm Forest Enterprises}

Various expenditures were listed as the main cost components in the production of woodlots from land preparation to biological rotation of trees. Descriptive statistics were used to summarize the costs of production of the high priority woodlot tree species as presented in Table 5. The single most important cost component as indicated in Table 5 was weeding constituting $44.6 \%$ of the total costs (averaging US\$266.66/acre). The other key cost components were pruning (17.1\%) and seedlings $(13.0 \%)$ averaging US\$99.62/acre and US\$77.96/acre, respectively. The least cost components were staking $(1.4 \%)$ and pitting (1.5\%) averaging a paltry US $\$ 8.44 /$ acre and US\$9.03/acre, respectively.
The total costs of production varied across the woodlot tree species and the counties. The highest total costs were for C. equisetifolia (at US\$640.73/acre) and least for $G$. arborea (at US\$534.98/acre). The highest cost per county was for C. equisetifolia in Lamu (at US\$684.44/acre). The least cost of production was registered for G. arborea in Kilifi County at US\$526.96/acre.

The costs of production for the field crops were incurred over one season and included, costs for: land preparation; seed; planting; fertilizers and pesticides; weeding; and harvesting. The total costs per acre for the highly ranked crops planted in one season per year averaged US\$138.73 (US\$134.70 for maize, US\$139.14 for cowpeas and US\$142.36 for green grams per acre).

Table 5. Cost of Production (US\$) of Common Woodlot Tree Species on One Acre in Coast

\begin{tabular}{|c|c|c|c|c|c|c|c|c|c|c|c|c|}
\hline \multirow{2}{*}{$\begin{array}{c}\text { Tree } \\
\text { Species }\end{array}$} & & \multicolumn{4}{|c|}{ C. equisetifolia } & \multicolumn{3}{|c|}{ G. arborea } & \multicolumn{3}{|c|}{ M. volkensii } & \multirow{2}{*}{$\%$} \\
\hline & & Kilifi & Kwale & Lamu & Total & Kilifi & Lamu & Total & Kilifi & Lamu & Total & \\
\hline \multirow{2}{*}{$\begin{array}{l}\text { Scale of } \\
\text { production }\end{array}$} & $\mu$ & 1.09 & 0.96 & 1.03 & 1.03 & 0.38 & 0 & 0.38 & 1 & 1 & 0.76 & \\
\hline & SE & 0.07 & 0.08 & 0.05 & 0.07 & 0.03 & 0 & 0.02 & 0 & 0 & 0 & \\
\hline \multirow{2}{*}{ Bush clearing } & $\mu$ & 37.00 & 43.57 & 26.44 & 35.67 & 30.00 & 25.00 & 27.50 & 25.00 & 30.00 & 31.13 & 4.5 \\
\hline & SE & 425.38 & 1095.63 & 311.38 & 610.8 & 114.71 & 166.67 & 140.69 & 57.35 & 16.67 & 37.01 & \\
\hline \multirow{2}{*}{$\begin{array}{l}\text { Removal of } \\
\text { stumps }\end{array}$} & $\mu$ & 25.56 & 42.17 & 70.00 & 45.91 & 5.00 & 5.00 & 5.00 & 30.00 & 30.00 & 28.74 & 4.9 \\
\hline & SE & 206.08 & 1096.24 & 1000 & 767.44 & 143.38 & 0 & 71.69 & 11.47 & 16.67 & 14.07 & \\
\hline \multirow{2}{*}{$\begin{array}{c}\text { Removal of } \\
\text { debris }\end{array}$} & $\mu$ & 15.00 & 22.50 & 30.00 & 22.50 & 30.00 & 30.00 & 30.00 & 30.00 & 30.00 & 26.67 & 4.9 \\
\hline & SE & 138.52 & 51.03 & 43.57 & 77.71 & 229.42 & 0 & 114.71 & 0 & 3.33 & 1.67 & \\
\hline \multirow{2}{*}{ Ploughing } & $\mu$ & 25.58 & 22.50 & 20.60 & 22.89 & 25.58 & 20.60 & 23.09 & 22.00 & 22.00 & 22.76 & 3.6 \\
\hline & SE & 138.77 & 111.8 & 77.46 & 109.34 & 34.41 & 0 & 17.21 & 11.47 & 16.67 & 14.07 & \\
\hline \multirow{2}{*}{ Seedlings } & $\mu$ & 150.00 & 100.00 & 100.00 & 116.67 & 25.00 & 25.00 & 25.00 & 80.00 & 80.00 & 77.96 & 13 \\
\hline & SE & 1.15 & 0 & 0 & 0.38 & 0 & 0 & 0 & 0 & 0 & 0 & \\
\hline \multirow{2}{*}{ Staking } & $\mu$ & 8.44 & 8.44 & 8.44 & 8.44 & 8.44 & 8.44 & 8.44 & 8.44 & 8.44 & 8.44 & 1.4 \\
\hline & SE & 14.99 & 14.99 & 0 & 9.99 & 6.88 & 0 & 3.44 & 2.29 & 0.83 & 1.56 & \\
\hline \multirow{2}{*}{ Pitting } & $\mu$ & 9.03 & 9.03 & 9.03 & 9.03 & 9.03 & 9.03 & 9.03 & 9.03 & 9.03 & 9.03 & 1.5 \\
\hline & SE & 0 & 160.86 & 0 & 53.62 & 22.94 & 0 & 11.47 & 11.47 & 8.33 & 9.9 & \\
\hline \multirow{2}{*}{ Planting } & $\mu$ & 28.50 & 28.50 & 28.50 & 28.50 & 28.50 & 28.50 & 28.50 & 28.50 & 28.50 & 28.50 & 4.6 \\
\hline & SE & 0 & 476.31 & 0 & 158.77 & 0 & 0 & 0 & 0 & 0 & 0 & \\
\hline \multirow{2}{*}{ Weeding } & $\mu$ & 268.80 & 226.19 & 278.59 & 257.86 & 268.80 & 278.59 & 273.69 & 268.80 & 278.59 & 266.66 & 44.6 \\
\hline & SE & 206.68 & 257.25 & 185.24 & 216.39 & 13.76 & 0 & 6.88 & 45.88 & 66.67 & 56.28 & \\
\hline \multirow{2}{*}{ Pruning } & $\mu$ & 96.60 & 70.33 & 112.83 & 93.26 & 96.60 & 112.83 & 104.72 & 96.60 & 112.83 & 99.62 & 17.1 \\
\hline & SE & 261.97 & 506.01 & 179.38 & 315.79 & 0 & 0 & 0 & 31.55 & 9.16 & 20.36 & \\
\hline \multirow{2}{*}{$\begin{array}{l}\text { TOTAL } \\
\text { COST }\end{array}$} & $\mu$ & 664.51 & 573.24 & 684.44 & 640.73 & 526.96 & 543.00 & 534.98 & 598.38 & 629.40 & 599.52 & 100 \\
\hline & SE & 126.69 & 342.75 & 163.37 & 210.93 & 51.41 & 15.15 & 33.28 & 15.59 & 12.57 & 14.08 & \\
\hline
\end{tabular}

Key: $\mu=$ mean cost; $\mathrm{SE}=$ standard error; $\%=$ percent 
Table 6. Annual Equivalent Values in US\$ for Woodlots and Field Crops

\begin{tabular}{cccccc}
\hline Enterprise & & Kilifi & Kwale & Lamu & Total \\
\hline \multirow{4}{*}{ Woodlots } & C. equisetifolia & 487.43 & 614.37 & 611.34 & 571.05 \\
& G. arborea & 256.72 & 248.56 & 240.39 & 248.56 \\
& M. volkensii & 278.28 & 273.80 & 269.29 & 273.79 \\
& Average for woodlots & 340.81 & 378.91 & 373.67 & 364.46 \\
\hline \multirow{3}{*}{ Field crops } & Maize & 179.40 & 221.00 & 235.00 & 211.80 \\
& Cowpeas & 243.00 & 251.10 & 251.00 & 248.36 \\
& Green grams & 71.70 & 72.10 & 72.20 & 72.01 \\
\hline
\end{tabular}

\section{Comparative Financial Analysis of Woodlots with Competing Field crops}

Key field crops in the region were mostly annuals including maize, cowpeas and green grams. Thus, annual equivalent values (AEVs) presented in Table 6 were computed for highly ranked field crops and woodlots using Microsoft Excel.

From Table 6, the woodlots had higher annual earnings than field crops. The annual earnings distributed over the biological rotation of woodlots averaged US\$364.46/acre unlike the field crops earnings that averaged US\$177.39/acre. The C. equisetifolia which was most profitable woodlot had AEV of US\$571.05/acre compared to cowpeas as the most profitable crop with annual earnings of US\$248.36. Equally, the average annual earnings of woodlots were higher than those for the crops in the counties covered affirming that woodlots were more profitable than field crops. The average annual woodlot earnings per acre were highest in Kwale County (US\$378.91) and least in Kilifi County (US\$340.81). On the other hand, the highest annual crop earnings per acre were realized in Lamu County (US\$186.07) and least in Kilifi County (US\$164.70).

\section{Discussion}

The woodlot species including A. indica, $C$. equisetifolia, E. camaldulensis, G. arborea, G. robusta and $M$. volkensii were the top ranking trees grown on smallholdings in the coast. The Cashewnuts and mango which also ranked high are categorized as commodity tree crops instead of woodlots. The woodlot species under FAO classification [19] and by Kleinn [20] are those trees used to establish a woodland or forest capable of small-scale production of forest products such as sawlogs, pulpwood, firewood and other specialty products; the categorization excludes the commodity tree crops. The ranking of woodlot species was in line with that done by Mbuvi et al. [21] indicating Mangifera indica, Azadirachta indica, C. equisetifolia, Senna siamea and $G$. arborea as the top ranked tree species grown on farms in the coast. On the other hand, the top ranking crops including maize, cowpeas and green grams were the highly consumed and better performing crops in the region. The general low ranking of sorghum could be attributed to the lack of markets, low producer prices, bird damage and limited production as locals regarded it as an inferior grain [22], [23], [24]. The beans production in the region was constraint by environmental factors that made its production difficult.

The $C$. equisetifolia was the top-ranked tree because of its short biological rotation, and its highly valued and in-demand poles. Trials established by KEFRI showed that Casuarina trees established with the spacing of $2 \mathrm{~m}$ by $2 \mathrm{~m}$ and densities up to 1,000 trees per acre $(2,500$ trees/ha), attain an average height of 9.6 metres and diameter of 2.9 inches at ground level by age 3 years thus attaining the required utilizable size of 4 to 6 inches diameter at ground level by biological rotation of 4 years. This short rotation and its soil ameliorating properties enhance its suitability for application in the farmers' rotation programme with field crops. The sandy soils that are low in fertility with poor water retention properties cover most parts of the region explaining why crop performance was low. Coastal soils are coarse textured and low in organic matter; the most common type being Arenosols, Luvisols and Acrisols [25]. However, the woodlot trees have taproots allowing them to exploit nutrients and water in deeper soil zones. Apart from market factors and the soil improvement properties of Casuarina, farmers also indicated that it provided environmental benefits including being a good windbreaker, and presented minimal suppression to the intercropped field crops due to its light canopy. Hozayn et al. [26] observed the positive impact of Casuarina on the soils and crop growth despite its reported allelopathic effect. The thick mat formation on the ground resulting from its high defoliation not only increases the organic matter in soil but also reduces soil erosion [27].

The provision of labour for agricultural operations is quite costly in Kenya due to the introduction of the minimum wage legislation explaining why the manual weeding of the woodlots was high. The number of seedlings for establishing $C$. equisetifolia in a unit area is comparatively higher because of closer spacing explaining why it had the highest cost. The cost figures computed by the study compare favourably with other studies done on 
woodlots. Although a study by Wekesa et al. [8] included the costs of land use, security, watering and transport leading to a total production of KES 114, 276 (US\$1,142.76) per acre, individual cost components compare well with our findings showing weeding and pruning as the costly operations in woodlot production. Wekesa et al. [6] observed that it required US\$1,205 to establish one hectare of $M$. volkensii up to canopy closure that is at three to four years of establishment.

The profitability of woodlots was higher than that for the field crops grown in the region. The figures concurred with the findings of other studies that woodlots in the coastal and drier parts of the country are more profitable than field crops. A study by Wekesa et al. [2] observed that trees were profitable than crops in Makueni and Kajiado. Wekesa et al. demonstrated that fruit trees including pawpaws (Carica papaya) and mangoes (Mangifera indica) were the most profitable farm activities on smallholdings. This was followed by the production of timber tree species of $M$. volkensii and Eucalyptus species (E. camaldulensis and E. tereticornis) whose profit margins were higher than those of crops. Across the counties, Lamu and Kwale had better returns from both crops and woodlots because of having better rains and soils than Kilifi [12], [21].

\section{Conclusion and Recommendation}

Woodlots were the most profitable farming activities among smallholder farmers in the Coast Region. The most profitable woodlots at their biological rotation were $C$, equisetifolia, M. Volkensii and G. Arborea.

Based on the foregoing, it is recommended that farmers be encouraged to engage in woodlots growing which could be inter-cropped with field crops at the initial stages of establishment to help diversify, and optimize incomes, food self-sufficiency and wellbeing at the farm level. The highly recommended woodlots for smallholder farmers are C, equisetifolia, M. Volkensii and G. Arborea. To help optimize production costs, farmers are advised to mechanize and use other non-labour intensive technologies to minimize labour cost.

\section{REFERENCES}

[1] C. C. Diosdado and S. A. Teresa, "Commercialization of Green Corn-Based Silage Production for Dairy in Cagayan Valley: Profitability and Viability Assessment," Universal Journal of Agricultural Research, vol. 9, no. 3, pp. 79-90, 2021. DOI: 10.13189/ujar.2021.090303.

[2] L. Wekesa, J. Mulatya, L. Kimotho and J. Wilson, "Profitability of crops and trees on small-scale farms on the southern drylands of Kenya," in 2nd KEFRI Scientific Conference, Nairobi, 1 to 4 November 2004.
[3] K. Senelwa, "Comparison of returns from wheat, maize and tree growing in Western Kenya," in Moi University Conference, Eldoret, Kenya, 2008.

[4] J. Cheboiwo and H. K. Maritim, "Comparative evaluation of farm forestry enterprises versus maize cultivation in western Kenya," in 2nd KEFRI Scientific Conference, Muguga, Kenya, 1 to 4 November 2004.

[5] J. Cheboiwo and Langat, D., "Smallholder tree growing income opportunities from farm forestry products in western Kenya," in 3rd KEFRI Scientific Conference, Muguga, Kenya, 6 to9 November, 2006.

[6] L. Wekesa, G. Muturi, A. Esilaba, G. Keya and S. Ihure, "Economic viability of Melia volkensii (Gurkii) production on smallholdings in drylands of Kenya," International Research Journal of Agricultural Science and Soil Science, vol. 83, no. 1, p. 364-369, 2012.

[7] B. Balozi, Senelwa, K., Kimani, G.K., Imo, M., Onkware, A. and Etie'gni, L., "The commercial profitability of growing hybrid euclyptus clones in the coast province," $J M H T$, vol. 20, no. 1, pp. 5-42, 2014.

[8] L. Wekesa, S. Mwalewa, K. Muema, J. Muthini, P. Riziki, P. Mukirae and C. Menya, "An economic assessment of woodlots for smallholder farms in the coast region of Kenya," East African Agricultural and Forestry Journal, vol. 83, no. 1, pp. 1-12, 2019.

[9] S. Keen and R. Standish, "Profit maximization, industry structure, and competition: a critique of neoclassical theory," Physica A: Statistical Mechanics and its Applications, vol. 370, no. 1, pp. 81-85, 2006.

[10] Kenya National Bureau of Statistics, Kenya population and housing census volume i: population by county and sub-county, KNBS, Nairobi: Government Printers, 2020.

[11] National Environment Management Authority, State of Coast Report for Kenya: Enhancing Integrated Management of Coastal and Marine Resources in Kenya, Nairobi: NEMA, Second Edition, 2017.

[12] Kenya Coastal Development Project, Coast region agriculture capability mapping, Mombasa: Ministry of Lands, Housing and Urban Development and Kenya Agricultural Research Institute, 2015.

[13] G. D. Israel, Determining sample size. Program evaluation and organizational development, Florida: IFAS, University of Florida. PEOD-6, 1992.

[14] B. G. Tabachnick and L. S. Fidell, Using multivariate statistics, New York (5th Ed.), 2007.

[15] S. Yaddanapudi and L. N. Yaddanapudi, "How to design a questionnaire," Indian J. Anaesth, vol. 63, no. 5, pp. 335-337, 2019

[16] L. Hultkrantz, L. Andersson and P. Mantalos, "Stumpage prices in Sweden 1909-2012: Testing for non-stationarity," Journal of Forest Economics, vol. 20, no. 1, pp. 33-46, 2014.

[17] L. Godsey, Economic Budgeting for Agroforestry Practices. Agroforestry in Action, Missouri: University of Missouri Center for Agroforestry, 2010.

[18] M. Rahman, I. M.S. and P. M.A.T., "Monitoring of changes in woodlots outside forests by multi-temporal Landsat 
imagery," Forest - Biogeosciences and Forestry, vol. 11, no. 1, pp. 162-170, 2018.

[19] Food and Agriculture Organization, FRA 2000 Terms and Definitions., Rome: FRA Working Paper 1, FAO Forestry Department, 1998.

[20] C. Kleinn, "A cautionary note on the minimum crown cover criterion in forest definitions," Canadian Journal of Forest Research, vol. 31, no. 2, pp. 350-356, 2001.

[21] M. T. Mbuvi, L. C. Wekesa, C. Wekesa, N. Leley, M. Ntabo, A. Eshitera, M. Karangi, L. Cheruiyot, P. Manyala, M. Okeyo, M. Sheikh, K. Kihara, M. Muchiri, P. Ongugo, A. Kala and B. Owuor, Capability mapping for growing high value tree species in the coast region of Kenya, Nairobi: Print Maxim, 2016.

[22] C. Grovermann, K. B. Umesh, S. Qui, B. G. Kumar, S. Sakamma and S. Moakes, "The Economic Reality of Underutilised Crops for Climate Resilience, Food Security and Nutrition: Assessing Finger Millet Productivity in India," Agriculture, vol. 8, no. 9, p. 131, 2018.

[23] D. Kilambaya and M. Witwer, "Analysis of incentives and disincentives for sorghum in Kenya," Technical notes series, MAFAP, FAO, Rome, 2013.

[24] R. M. Ogeto, E. Cheruiyot, P. Mshenga and C. N. Onyari, "Sorghum production for food security: A socio-economic analysis of sorghum production in Nakuru County, Kenya," African Journal of Agricultural Research, vol. 16, no. 5, pp. 722-731, 2020.

[25] G. N. Karuku, "Soil and water conservation measures and challenges in Kenya; a review," Cur Inves Ag. Cur Res, vol. 2, no. 5, pp. 259-279, 2018.

[26] M. Hozayn, T. A. El-Shahewy, A. A. Abd El-Mohen and M. A. Darwish, "Allelopathic effect of casuarina equestifolia L. on wheat, associated weeds and nutrient content in the soil," African Journal of Agricultural Research, vol. 10, no. 14, pp. 1675-1683, 2015.

[27] R. M. Patel, M. B. Tande, S. M. Patel, M. K. Desai and D. B. Jadeja, "Influence of casuarina equisetifolia 1. raised at different spacings on fertility status of soil and tree growth," Journal of on-Timber Forest Products, vol. 20, no. 1, pp. 43-45, 2013. 